\title{
Вплив розчинів гідроксиетилкрохмалів на коагуляційний гемостаз, крововтратуі результати лікування пацієнтів з ішемічною хворобою серця
}

\author{
Гурін П.В.
}

\author{
ДУ «Національний інститут хірургії та трансплантології імені О. О. Шалімова НАМН України» (Київ)
}

\begin{abstract}
Наведено результати застосування колоїдних та кристалоїдних розчинів під час оперативного втручання у пацієнтів з ішемічною хворобою серця. Досліджено вплив на систему коагуляційного гемостазу колоїдних розчинів та пов'язані із цим периопераційні ускладнення. У дослідження включені 40 пацієнтів, оперованих у НIXТ імені О. О. Шалімова з приводу ішемічної хвороби серця, яким було виконано коронарне шунтування на працюючому серці: група дослідження становила 20 пацієнтів (в інтраопераційному періоді застосовували розчини гідроксиетилкрохмалю 130/0,4; група порівняння - 20 пацієнтів (в інтраопераційному періоді застосовували виключно кристалоїдні розчини). Аналізували результати загального і біохімічного аналізу крові, електролітний, кислотно-основний і газовий склад крові, визначали протромбіновий час, протромбіновий індекс, міжнародне нормалізоване відношення, активований частковий тромбопластиновий час, показники тромбоеластометрії. Статистичний аналіз матеріалу проводився за допомогою стандартних методів із застосуванням пакету прикладних програм "MS Excel” та "Stat Plus 2007 Professional”. Оцінювали середнє значення, стандартні помилки, достовірність відмінностей. Для оцінки міжгрупової різниці застосовували параметричний t-критерій Стьюдента, при визначенні зв’язків між показниками - кореляційний аналіз за Пірсоном. Отримані результати довели негативний вплив на систему коагуляційного гемостазу колоїдних розчинів (зміни показників тромбоеластометрії, протромбінового часу та протромбінового індексу) та збільшення частоти післяопераційних ускладнень (крововтрата, потреба вгемотрансфузії, збільшення часу перебування у відділенні інтенсивної терапії та стаціонарі). Одержані результати дають перспективи в подальшому вивченні впливу колоїдних розчинів на коагуляційний гемостаз під час інших оперативних втручань (торакальних, абдомінальних тощо), а також в застосуванні методу тромбоеластометрії в клінічній практиці для ранньої діагностики порушень коагуляційного гемостазу.
\end{abstract}

Ключові слова: гідроксиетилкрохмаль, коронарне шунтування, коагуляційний гемостаз, крововтрата, тромбоеластометрія.

Колоїдні та кристалоїдні розчини використовуються для підтримки тканинної перфузії та оксигенації під час оперативних втручань, інтенсивного лікування тощо. Використання колоїдних розчинів під час великих хірургічних втручань $є$ суперечливим, і ні безпечність, ні ефективність ГЕК 130/0,4 не продемонстровані в системних мета-аналізах [1-3].

Під час операції об’єм циркулюючої крові (ОЦК) підтримується кристалоїдами i, зрештою, колоїдом, що залишається в судинному руслі, тоді як від 30 до $60 \%$ кристалоїдних розчинів можуть бути «втрачені» В інтерстиційному просторі [4]. 3 одного боку, використання колоїдних розчинів для підтримки ОЦК під час оперативного втручання вважається доцільним при суттєвій крововтраті, а з іншого боку, вважається, що використання синтетичних колоїдів впливає на коагуляційний гемостаз, а це певною мірою призводить до збільшення крововтрати. Тому доцільність використання колоїдних розчинів під час операції залишається невирішеним питанням [5].
У більшості клінік моніторинг пери операційного коагуляційного гемостазу спирається на клінічну оцінку та класичні показники коагулограми: протромбіновий час (ПЧ), протромбінів індекс (ПІ), міжнародне нормалізоване відношення (МНВ). Проте ці показники були розроблені для перевірки відсутності коагуляційних факторів, а не для прогнозування ризику кровотечі або для керування гемостатичною терапією. На відміну від класичних коагуляційних тестів, віско-еластична оцінка цільної крові дає можливість швидкої діагностики причин кровотечі і може відображатися в режимі реального часу безпосередньо в операційній. Таким чином, Європейське товариство анестезіологів (ESA) рекомендує використання периопераційного моніторингу згортання крові, наприклад тромбоеластометрію, для цілеспрямованого лікування коагулопатії[6].

Мета дослідження -вивчити вплив розчинів гідроксиетилкрохмалів на коагуляційний гемостаз під час коронарного шунтування на працюючому серці. 
Матеріали та методи. В основу дослідження покладено ретроспективний аналіз історій хвороби пацієнтів, яким із січня по серпень 2018 року було виконано ізольоване КШ на працюючому серці. Було вибрано 40 історій хвороб пацієнтів, яким виконувалось ізольоване КШ-3 на працюючому серці. Критеріями виключення пацієнтів із дослідження були: фракція викиду лівого шлуночка менша за 50\%, початковий рівень креатиніну крові $>140$ мкмоль/л, рівень гемоглобіну <120 г/л, кількість тромбоцитів $<180 \times 10^{9} /$ л, доопераційнакоагулопатія, печінкова дисфункція (АЛТ $>40$ ОД/л, АСТ $>40$ ОД/л), повторна операція КШ, ургентне оперативне втручання. Всім пацієнтам антитромбоцитарні препарати (клопідогрель, тікагрелор) та аспірин були відмінені більше ніж за 5 днів до оперативного втручання.

Пацієнти були розподілені на дві рівні групи по 20 осіб: 1-ша група (група дослідження) - пацієнти, у яких в інтраопераційному періоді застосовувалися розчин ГЕК 130/0,4 (максимальна доза не перевищувала 20 мл/кг); 2-га група (група порівняння) - пацієнти, у яких колоїдні розчини в інтраопераційному періоді не застосовувались, а в програму інфузійної терапії були включені лише кристалоїдні розчини. Весь об'єм колоїдного розчину вводився до початку основного етапу операції. Загальний об'єм розчину ГЕК становив 1000 мл у кожного пацієнта 1-ої групи.

Лабораторний контроль включав у себе:визначення загального аналізу крові (гемоглобін, гематокрит, кількість еритроцитів, лейкоцитів, тромбоцитів), біохімічний аналіз крові (загальний білок, глюкоза, креатинін, сечовина), електролітного, кислотно-основного та газового складу крові.

Лабораторний контроль коагуляційного гемостазу включав у себе визначення ПЧ, ПІ, МНВ, АЧТЧ та TEM.

Тромбоеластометрія - це метод лабораторної діагностики системи гемостазу, що дозволяє протягом одного тесту оцінити всі ланки системи згортання (тромбоцитарну, коагуляційну, фібриноліз). Цей метод широко застосовується для діагностики порушень у системі коагуляційного гемостазу під час масивної крововтрати (політравма, резекції печінки великого об’єму, трансплантація печінки тощо).

Основні параметри ТЕМ:

1. СТ (clotting time) - час від початку дослідження до початку утворення згустку (початок згортання крові, утворення тромбіну, початок полімеризації згустку).

2. CFT (clot formation time) - час від початку утворення згустку до досягнення ним щільності 20 мм.

3. MCF (maximum clot firmness) - максимальна амплітуда щільності згустку (збільшення полімеризації згустку за рахунок полімеризації фібрину, тромбоцитів та F XIII).
4. ML (maximum lysis) - зменшення щільності згустку, відносно його максимальної щільності, виражене у відсотках (діагностика гіперфібринолізу).

Оцінку показників ТЕМ проводили в режимах intem та extem, реєструючи наведені вище показники. В режимі intem реєстрували активацію внутрішнього шляху згортання крові (дозволяє оцінити фактори згортання I, II, V, VIII, IX, X, XI, XII, тромбоцити, фібриноліз), в режимі еxtem - активацію зовнішнього шляху згортання крові (дозволяє оцінити фактори згортання I, II, V, VII, X, тромбоцити, фібриноліз).

Результати та обговорення.Пацієнти досліджуваних груп не відрізнялися між собою за клінічними та лабораторними показниками перед проведенням оперативного втручання. Середній вік пацієнтів 1-ї групи становив $60,7 \pm 7,6$ років, $2-i ̈-61,2 \pm 8,7$ років $(\mathrm{p}=0,27)$. Усі пацієнти мали стенокардію напруження різного функціонального класу, а оцінка периопераційного ризику за шкалою EUROSCOREскалала1,33 $\pm 0,4 \%$ і $1,22 \pm 0,38 \%$ відповідно у пацієнтів 1-ї та 2-ї групи. Також не було виявлено суттєвих відмінностей удоопераційних показниках гемоглобіну, ПЧ, ПІ та МНВ.

Дослідження показників коагуляційного гемостазу проводили в інтра- та післяопераційному періоді. Аналіз ТЕМ проводили після введення всієї дози розчину ГЕК, але перед введенням гепарину. Така умова $є$ важливою, оскільки гепарин є прямим антикоагулянтом і спричиняє зміну показників коагулограми. У середньому доза розчину ГЕК 130/0,4 у пацієнтів групи дослідження склала $11,7 \pm 1,5$ мл/кг. Аналізуючи результати ТЕМ, необхідно звернути увагу на те, що у пацієнтів 1-ї групи відбувалися зміни в показнику СТ в режимі extem, що може свідчити про недостатність факторів згортання, зумовленугемодилюцією. Нормальним показник CT extem вважався в межах 38-79 секунд. Інші показники ТЕМ в обох режимах не відрізнялися від норми. У групі 2 у жодного з пацієнтів не спостерігалося відхилення показників ТЕМ від норми. В табл. 1 представлено показники коагуляційногогемостазу та ïx порівняння між групами пацієнтів в інтра- та післяопераційному періодах.

Як можна побачити з таблиці, у пацієнтів 1-ї групи були зареєстровані порушення коагуляційного гемостазу після застосування розчинів ГЕК яК в інтра-, так і в ранньому (перша післяопераційна доба) післяопераційному періоді. Зміни коагуляційного гемостазу реєструвались і в показниках ТЕМ у пацієнтів 1-ї групи(CT-extem). Відновлення коагуляційного потенціалу в пацієнтів 1-ї групи спостерігалось через 48 годин після проведеного оперативного втручання. Показники коагуляційного гемостазу в пацієнтів 2-ї групи суттєво не відхилялися від нормальних величин як в інтра-, так і в післяопераційному періоді.

Зміни в системі коагуляційного гемостазу, що виникали в периопераційному періоді, призве- 


\section{Таблиця 1}

Показники коагуляційного гемостазу в

периопераційному періоді

\begin{tabular}{|c|c|c|c|}
\hline Показник & $\begin{array}{c}\text { Група } 1 \\
\mathrm{~N}=20, \mathrm{M} \pm \mathrm{SD}\end{array}$ & $\begin{array}{c}\text { Група } 2 \\
\mathrm{~N}=20, \mathrm{M} \pm \mathrm{SD}\end{array}$ & $\mathbf{P}$ \\
\hline CTextem, сек. & $102,1 \pm 15,4$ & $66,3 \pm 5$ & 0,0001 \\
\hline $\begin{array}{l}\text { ПЧ - початок операції, } \\
\text { сек. }\end{array}$ & $12,3 \pm 2,4$ & $12,4 \pm 2,6$ & 0,9 \\
\hline $\begin{array}{l}\text { ПЧ - кінець операції, } \\
\text { сек. }\end{array}$ & $20,6 \pm 3,8$ & $18,5 \pm 2$ & 0,04 \\
\hline $\begin{array}{l}\text { ПЧ - } 24 \text { години п/о, } \\
\text { сек. }\end{array}$ & $18,6 \pm 1,6$ & $17,3 \pm 1,7$ & 0,02 \\
\hline ПЧ - 48 годин п/о, сек. & $18,1 \pm 0,82$ & $17,7 \pm 1,4$ & 0,27 \\
\hline $\begin{array}{l}\text { ПІ - початок операції, } \\
\%\end{array}$ & $92 \pm 6,4$ & $91,5 \pm 6,8$ & 0,81 \\
\hline ПІ - кінець операції, \% & $65,1 \pm 12,1$ & $78,4 \pm 7,7$ & 0,0002 \\
\hline ПІ - 24 години п/о, \% & $73,5 \pm 6,7$ & $83,7 \pm 7,6$ & 0,0001 \\
\hline ПІ - 48 годин п/о, \% & $81,1 \pm 4,3$ & $84,2 \pm 6,7$ & 0,08 \\
\hline $\begin{array}{l}\text { МНВ - початок } \\
\text { операції }\end{array}$ & $1,15 \pm 0,12$ & $1,2 \pm 0,17$ & 0,93 \\
\hline МНВ - кінець операції & $1,76 \pm 0,32$ & $1,55 \pm 0,24$ & 0,02 \\
\hline МНВ - 24 години п/о & $1,58 \pm 0,28$ & $1,37 \pm 0,17$ & 0,006 \\
\hline МНВ - 48 годин п/о & $1,37 \pm 0,19$ & $1,34 \pm 0,16$ & 0,59 \\
\hline
\end{tabular}

ли до підвищеної крововтрати у пацієнтів 1-ї групи. Так,інтраопераційна крововтрата в 1-й групі становила $608 \pm 138$ мл проти $452 \pm 65$ мл у пацієнтів групи порівняння.

Схожа картина спостерігається і в післяопераційному періоді. Так, крововтрата за перші 24 години після операції у пацієнтів 1-ї групи склала $346 \pm 94$ мл, за 2-гу післяопераційну добу - $143 \pm 56$ мл, а сумарна післяопераційна крововтрата склала $489 \pm 122$ мл. У пацієнтів 2-ї групи крововтрата за перші 24 години після операції склала $266 \pm 60$ мл, за 2-гу післяопераційну добу - $133 \pm 56$ мл, а сумарна післяопераційна крововтрата становила $399 \pm 96$ мл.

Величини периопераційної крововтрати та показників післяопераційного періоду в обох групах наведено в табл. 2.

Як видно з табл. 2, рівень гемоглобіну у пацієнтів групи порівняння був достовірно вищим у кінці операції, що зумовлено меншою величиною крововтрати. Узв'язку з підвищеною крововтратою 3(15\%) пацієнти 1-ї групи потребували трансфузії еритроцитарної маси в післяопераційному періоді. Також у 2 пацієнтів 1-ї групи в післяопераційному періоді було зареєстровано підвищення креатиніну крові понад 140 мкмоль/л. В подальшому, при дослідженні рівня креатиніну у цих пацієнтів, було виявлено, що через 4 доби після проведеного оперативного втручання рівень креатиніну крові відновлювався до нормальних значень.

\section{Таблиця 2}

Порівнянняпериопераційної крововтрати та показників післяопераційного періоду

\begin{tabular}{|c|c|c|c|}
\hline Показник & $\begin{array}{c}\text { Група } 1 \\
\mathrm{~N}=20, \mathrm{M} \pm \mathrm{SD}\end{array}$ & $\begin{array}{c}\text { Група } 2 \\
\text { N=20, } \\
\text { M=SD }\end{array}$ & $\mathbf{P}$ \\
\hline $\begin{array}{l}\text { Інтраопераційна крово- } \\
\text { втрата, мл }\end{array}$ & $608 \pm 138$ & $452 \pm 65$ & 0,001 \\
\hline $\begin{array}{l}\text { Крововтрата - } 24 \text { год. } \\
\text { п/о, мл }\end{array}$ & $346 \pm 94$ & $266 \pm 60$ & 0,003 \\
\hline $\begin{array}{l}\text { Крововтрата - } 48 \text { год. } \\
\text { п/о, мл }\end{array}$ & $143 \pm 56$ & $133 \pm 49$ & 0,55 \\
\hline $\begin{array}{l}\text { Сумарна післяопераційна } \\
\text { крововтрата, мл }\end{array}$ & $489 \pm 122$ & $399 \pm 96$ & 0,01 \\
\hline $\begin{array}{l}\text { Гемоглобін - початок } \\
\text { операції, г/л }\end{array}$ & $134 \pm 15,6$ & $138 \pm 18,9$ & 0,47 \\
\hline $\begin{array}{l}\text { Гемоглобін - кінець } \\
\text { операції, г/л }\end{array}$ & $110,4 \pm 12,2$ & $126 \pm 10,1$ & 0,0001 \\
\hline $\begin{array}{l}\text { Час перебування у ВIT, } \\
\text { год. }\end{array}$ & $52 \pm 7$ & $43,2 \pm 10$ & 0,002 \\
\hline $\begin{array}{l}\text { Час перебування в } \\
\text { стаціонарі п/о, діб }\end{array}$ & $8,8 \pm 1,5$ & $6,7 \pm 1,3$ & 0,002 \\
\hline
\end{tabular}

Час знаходження у відділенні інтенсивної терапії та стаціонарі був вищим у групі пацієнтів, яким застосовували розчин ГЕК 130/0,4 (група 1). Госпітальна летальність була нульовою в обох групах.

\section{Висновки}

1. Використання розчинів ГЕК 130/0,4 призводить до зміни показників коагуляційного гемостазу.

2. Використання розчинів ГЕК 130/0,4 збільшує периопераційну крововтрату, а також потребу в гемотрансфузії та час перебування в стаціонарі.

3. Тромбоеластометріяпоказала свою ефективність для ранньої діагностики порушень коагуляційного гемостазу під час використання розчинів ГЕК 130/0,4, а не лише при масивній крововтраті.

4. Під час планових оперативних втручань перевагу слід віддавати кристалоїдним розчинам в якості базових.

\section{Література}

1. PatelA, WaheedU, BrettSJ. Randomised trials of $6 \%$ tetrastarch (hydroxyethyl starch 130/0.4 or 0.42 ) for severe sepsis reporting mortality: systematic review and metaanalysis. IntCareMed 2013; 39:811-822.

2. Gattas DJ, Dan A, Myburgh J, et al. Fluid resuscitation with $6 \%$ hydroxyethyl starch (130/0.4 and 130/0.42) in acutely ill patients: systematic review of effects on mortality and treatment with renal replacement therapy. IntensiveCareMed 2013; 39:558-568.

3. Perel P, Roberts I, Ker K.Colloids versus crystalloids for fluid resuscitation in critically ill patients.CochraneDatabas eSystRev2013;2:CD000567. 
4. Zaar M, Lauritzen B, Secher NH, et al. Initial administration of hydroxyethyl starch vs. lactated Ringer after liver trauma in the pig. Br J Anaesth 2009; 102:221-226.

5. Kelleher MC, Buggy DJ. Pendulum swings again: crystalloid or colloid fluid therapy? Br J Anaesth 2014; 113:335-337.
6. Kozek-Langenecker SA, Afshari A, Albaladejo P, et al. Management of severe perioperative bleeding: guidelines from the European Society of Anaesthesiology. Eur $J$ Anaesthesiol 2013; 30:270-382.

\section{Influence of hydroxyethylstarch solutions on coagulation, blood loss and results of treatment of patients with ischemic heart disease}

Gurin P.

\section{O. O. Shalimov National Institute of Surgery and Transplantology National Academy of Medical Science of Ukraine (Kyiv)}

The results of application of colloidal and crystalloid solutions during surgical intervention in patients with coronary heart disease are presented. The influence on the system of coagulation hemostasis of colloidal solutions and related perioperative complications have been investigated. The study included 40 patients operated in A. A. Shalimov National Institute of Surgery and Transplantology about coronary heart disease who performed off-pump coronary bypass grafting surgery (cabg): a study group of 20 patients (in the intraoperative period, solutions of hydroxyethyl starch $130 / 0.4$ were used, and a comparison group of 20 patients (only crystalloid solutions were used during the intraoperative period). The results of general and biochemical blood tests, electrolyte, acid-base and gas composition of blood, determined the prothrombin time, the prothrombin index, the international normalized ratio, the active partial thromboplastin time, thromboelastometry indices Statistical analysis of the material was performed using standard methods using the application package "MS Excel" and "StatPlus 2007 Professional". Estimates of mean, standard errors, reliability of differences. To estimate the difference between groups, parametric t- Investigator's criterion, when the relationships between the indicators are determined, is a correlation analysis by Pearson. The obtained results have adversely affected the system of coagulation hemostasis of colloidal solutions (changes in the parameters of thromboelastometry, prothrombin time and prothrombin index), and an increase in the frequency of postoperative complications (blood loss, need for blood transfusion, increase in the time of stay in the intensive care unit and in-patient department). The obtained results give prospects for further study of the influence of colloidal solutions on coagulation hemostasis during other surgical interventions (thoracic, abdominal, etc.), as well as the use of the method of thromboelastometry in clinical practice for the early diagnosis of coagulation hemostasis disorders.

Keywords: hydroxyethylstarch, off-pump coronary artery bypass grafting surgery, coagulationhemostasis, bloodloss, thromboelastometry, postoperativecomplications. 